\title{
Przebaczenie krzywdy jako uczynek miłosierdzia
}

Ogłaszając Rok Miłosierdzia, papież Franciszek powiedział: „Jest moim gorącym życzeniem, aby chrześcijanie przemyśleli podczas Jubileuszu uczynki miłosierdzia co do ciała i co do duszy. Będzie to sposób na obudzenie naszego sumienia, często uśpionego, w obliczu dramatu ubóstwa, a także umożliwi nam coraz głębsze wejście w serce Ewangelii, gdzie ubodzy są uprzywilejowani dla Bożego miłosierdzia" (MV 15)'. Jeden z uczynków miłosierdzia co do duszy to: „Krzywdy cierpliwie znosić”, co w języku włoskim wyrażono w słowach: „Przebaczać krzywdy”. Ten uczynek w szczególny sposób odnosi się do wzrastania osoby i uzdrawiania relacji. Tylko miłość miłosierna ubogaca człowieczeństwo i pozwala wychodzić naprzeciw ludzkim słabościom. W niniejszym artykule ${ }^{2}$ podejmę próbę ukazania tej prawdy w perspektywie teologicznej, odnosząc się także do doświadczeń, rodzących się w ramach realizacji charyzmatu jedności Chiary

* Ks. Jesús Morán Cepedano jest współprezydentem Ruchu Focolari, założonego w 1943 roku we Włoszech przez Chiarę Lubich (1920-2008); jest filozofem (Università Autonoma di Madrid) oraz teologiem (Pontificia Università Cattolica di Santiago del Cile), członkiem Scuola Abba - interdyscyplinarnego centrum naukowego Ruchu Focolari w Rocca di Papa (Włochy), w zakresie antropologii teologicznej i teologii moralnej. Kontakt: Via di Frascati, 306, 00040 Rocca di Papa RM, Włochy; e-mail: jesus.moran@focolare.org.

${ }^{1}$ Franciszek, Bulla Misericordiae Vultus Ojca Świętego Franciszka o nadzwyczajnym jubileuszu miłosierdzia (Wrocław: Wydawnictwo TUM, 2015).

2 Jest to artykuł opracowany w oparciu o katechezę wygłoszoną 2 marca 2016 w Pompejach, w ramach cyklu katechez na temat uczynków miłosierdzia. 
Lubich $^{3}$. Jego istotą jest odniesienie do osoby, które polega na budowaniu relacji miłości, wyrażającej się w sprawiedliwości, miłosierdziu, odporności psychicznej i przebaczeniu. Refleksja prowadzi także do analizy dwóch konkretnych propozycji budowania postawy przebaczenia: sztuki milowania i paktu milosierdzia. Są to metody edukacyjne, możliwe do aplikacji także wśród wyznawców innych religii oraz osób o poglądach niereligijnych.

\section{Przebaczenie jako akt heroiczny}

Na początku chciałabym przywołać dramatyczne doświadczenie moich znajomych z miasta Meksyk: jakiś czas temu z domu zniknął ich jedyny syn. Długi czas poszukiwań był dla nich okresem wielkiego cierpienia i udręki. Któregoś dnia poproszono ich o identyfikację zwłok człowieka, który mógłby być ich synem. Istotnie, gdy je zobaczyli, potwierdzili, że to on. Były to zwłoki osoby porwanej, torturowanej i zamordowanej, które w stanie rozkładu znaleziono we wspólnym grobie. Potworny obraz! Rodzice przebaczyli jednak mordercom. Oto heroiczność przebaczenia i miłosierdzia. To właśnie takie czyny umacniają człowieczeństwo i jakby jakaś niewidzialna sieć podtrzymują ludzkość.

Zastanawiając się nad konkretnymi przykładami, które pomogłyby zrozumieć, w jaki sposób każdy może być mediatorem pojednania w codziennym życiu, warto odwołać się do refleksji biskupa Werony, Franca G. Brambilli:

Jeżeli zatem uczynki miłosierdzia co do ciała dotyczą sfery życia praktycznego, jego podstawowych potrzeb (pierwszych pięć: głód, pragnienie, ubranie, dom i praca) oraz jego cierpień granicznych (choroba, więzienie i śmierć), to uczynki miłosierdzia co do duszy dotyczą wzrastania osoby (wykształcenie, radzenie, pociecha) oraz pojednania $w$ relacjach (braterskie upomnienie, darowanie urazów, znoszenie drugiego) aż do modlitwy za wszystkich, z postawa, która umiejscawia nasze działanie w obszarze Bożego miłosierdzia. Należy podkreślić, że

3 Celem założonego przez nią Ruchu Focolari jest dążenie do realizowania modlitwy Jezusa: „Ojcze spraw, aby wszyscy stanowili jedno” (J 17, 21). Ruch jest obecny w 194 krajach na wszystkich kontynentach, a w 80 krajach posiada swoje centra. Oprócz katolików należą do niego chrześcijanie z 350 Kościołów i wspólnot kościelnych. Duchowość i cele Ruchu podzielają także, w różnym zakresie, wyznawcy innych religii oraz osoby o przekonaniach niereligijnych. 
chociaż samo ich sformułowanie może wydawać się trochę przestarzałe, to jednak uczynki co do duszy ogniskują w sobie tę ludzką biedę, która współcześnie ma ogromny depresyjny wpływ na życie duchowe, osobiste i społeczne ${ }^{4}$.

W świetle tych słów przebaczenie jawi się jako czyn miłosierdzia - czyn heroiczny, dzięki któremu mogą zostać przezwyciężone kryzysy, trawiące współczesny świat. Nim jednak przyjrzymy się, na czym polega wartość przebaczenia, należy zatrzymać się nad zjawiskiem krzywdy i kryteriami odniesień do innego człowieka.

\section{Krzywda}

Aby mówić o przebaczeniu krzywd jako uczynku miłosierdzia, trzeba najpierw zapytać, czym jest krzywda. Słowo „krzywda” w języku włoskim brzmi offesa i pochodzi z języka łacińskiego ob-fendere, co oznacza: „odepchnąć, uderzyć”. Krzywda może pojawić się w sferze fizycznej, psychicznej, moralnej:

- krzywda fizyczna jest wykroczeniem przeciwko nienaruszalności i godności ciała osoby ludzkiej, a zatem dotyczy jej życia i zdrowia, niekiedy prowadzi do choroby i śmierci;

- krzywda psychiczna jest zakwestionowaniem szacunku dla życia psychicznego osoby, naruszeniem jej zdrowia psychicznego;

- krzywda moralna rodzi się z braku szacunku dla sumienia osoby, a zatem dla jej wolności, włącznie z wolnością religijną.

Krzywda może być dokonana słownie, czynem lub przez zaniedbanie. Krzywda może mieć formę obelgi skierowanej do kogoś, obrazy, hańby, gwałtu, ataku, upokorzenia, szkód materialnych. Krzywdy dotyczą relacji międzyosobowych i mogą być dokonane świadomie lub nieświadomie wobec osoby, grupy osób, narodu. Życie codzienne dostarcza wielu przykładów konkretnych krzywd. Mogą one występować w relacjach pomiędzy kobietą i mężczyzna, między młodymi i dorosłymi, bogatymi i biednymi, w środowisku rodziny, w życiu społecznym, w gospodarce, pracy zawodowej, życiu politycznym, szkole, w środowisku naturalnym, wreszcie we wspólnotach religijnych, także we wspólnocie Kościoła. Ich przyczyny mogą być różne: różnice charakterologiczne, despotyzm, nadużycie władzy, rywalizacja,

${ }^{4}$ Franco G. Brambilla, „L'onda del rinnovamento. Rimettere al centro il primato di Dio. La radice del Vaticano II", Il Regno attualità 11 (2015): 715-719. 
stres, któremu podlegają liczne osoby. W każdym przypadku są one oznaką niedojrzałości i ignorancji, świadczą o braku szacunku i miłości w odniesieniu do innego człowieka.

W świecie coraz bardziej zglobalizowanym, w którym spotykamy się z ludźmi z różnych kultur, z nieskończoną różnorodnością wrażliwości i kryteriów moralnych, uniwersalną pomocą w zrozumieniu istoty krzywdy może być zapis z Powszechnej deklaracji praw człowieka, sformułowanej i podpisanej przez wiele krajów po II wojnie światowej. W artykule pierwszym czytamy: „Wszyscy ludzie rodzą się wolni i równi pod względem swej godności i swych praw. Są oni obdarzeni rozumem i sumieniem i powinni postępować wobec innych w duchu braterstwa". Akcent jest tu położony na godność każdej osoby ludzkiej oraz na braterstwo. Ilekroć ta godność nie jest brana pod uwagę i nie jest szanowana, wyrządzana jest krzywda.

Prawom - jak wiadomo - odpowiadają ściśle określone obowiązki. Kompendium nauki społecznej Kościoła w rozdziale czwartym przedstawia nauczanie Kościoła na temat „osoby ludzkiej i jej praw”. Według niego zasadniczym kryterium odniesień do innego człowieka jest zawsze miłość: „Tylko miłość może całkowicie zmienić człowieka”" Faktycznie, Kościół postrzega środowiska: społeczne, polityczne, ekonomiczne, kulturowe jako przestrzeń „cywilizacji miłości”, której on sam z natury swej jest instrumentem i widocznym znakiem. Faktem jest jednak, że tworzenie takiej cywilizacji musi się rozpoczynać od konkretnego człowieka, musi być realizowane we wszystkich relacjach, które wymagają właściwej postawy.

Wyrządzenie krzywdy domaga się przeproszenia. W świetle powyższego warto przypomnieć gest Jan Pawła II, który z okazji Wielkiego Jubileuszu Roku 2000, ku zaskoczeniu wielu, zechciał prosić o przebaczenie krzywd wyrządzonych przez ludzi Kościoła i świat chrześcijański ${ }^{6}$ w ciągu dziejów, poprzez krucjaty, dyktatury, podziały między Kościołami; krzywd wyrządzonych kobietom, Żydom, środowiskom nauki, ,reformatorom”, Indianom, ofiarom rasizmu, czarnoskórym itd. W ostatnich czasach byliśmy świadkami tego, jak również papieże Benedykt XVI i Franciszek prosili o przebaczenie ofiary pedofilii i wszelkiego rodzaju nadużyć w Kościele.

${ }^{5}$ Por. Jan Paweł II, Novo millennio ineunte, nr 49-51 (Poznań: Pallotinum, 2001); Papieska Rada Iustitia et Pax, Kompendium nauki społecznej Kościoła, nr 583 (Kielce: Jedność, 2005).

${ }^{6}$ Zob. Luigi Accattoli, Quando il Papa chiede perdono. Tutti i mea culpa di Giovanni Paolo II (Milano: Mondadori, 1999); wyd. polskie: Kiedy Papież prosi o przebaczenie. Wszystkie ,,mea culpa” Jana Pawła II (Kraków: Wydawnictwo Znak, 1999). 


\section{Doświadczenie krzywdy jako przestrzeń dojrzewania}

Chrześcijaństwo głosi, że każdy człowiek jest powołany - na wzór Jezusa - do wzrastania w latach, mądrości i łasce, by dojść do pełnej samorealizacji, gdyż został stworzony przez Boga Miłość, przez miłość i dla miłości. Miłość jest prawem życia. Miłość powinna kształtować bycie i wszystkie postawy człowieka. Nikt nie rodzi się kompletnie uformowany, dlatego też konieczne jest owo wzrastanie:

- „wzrastanie w latach” - oznacza wzrastanie fizyczne, psychiczne, emocjonalne;

- „wzrastanie w mądrości” - oznacza wzrastanie w poznawaniu życia, jego tajemnicy, sekretów, dynamiki, i kształtowaniu zgodnych z tą wiedzą postaw; obejmuje to także odpowiednią formację kulturową;

- „wzrastanie w łasce” - oznacza wzrastanie w miłości, aż do uczynienia ofiary z siebie, to znaczy aż do ofiarowania własnego życia z miłości.

Wskazany powyżej proces jest „majeutyką” człowieka, jest dążeniem do osiagnięcia przez ludzki byt pełni człowieczeństwa. Ów proces rozciaga się na całe życie człowieka. Życie jest bowiem nieustanym wydobywaniem prawdziwego „Ja”, realizowanym zarówno w okresie dzieciństwa, następnie młodości, dorosłości, wreszcie starości.

W Galerii Akademii Sztuk Pięknych we Florencji znajdują się cztery niedokończone posagi Michała Anioła, zatytułowane „Jeńcy”, które nie doczekały się wykończenia, w przeciwieństwie do innych jego rzeźb: Piety, Dawida czy Mojżesza. W każdym z tych marmurowych bloków artysta „widział” jednak postać, a następnie za pomocą dłuta starał się ją wydobyć. W tym przypadku dzieło to nie znalazło wykończenia. Tak samo Bóg chce wydobyć z każdego człowieka jego prawdziwe „Ja”, choć jest to proces żmudny, obejmujący zarówno miłość, jak i cierpienie, w tym doznane krzywdy.

Wydobywanie autentycznego „Ja” dokonuje się przede wszystkim w rodzinie, w której człowiek doświadcza zarówno miłości, jak i krzywdy, a przy tym uczy się przebaczać. Jak pisze Franciszek o wychowaniu dzieci w rodzinie:

Przyzwyczajając je do opowieści ewangelicznych, do przypowieści. Prowadząc z nimi dialog, a przede wszystkim doświadczając z nimi miłosierdzia. Pozwalając im zrozumieć, że w życiu można się pomylić, ale że ważnym jest zawsze powstawać. (...) Rodzina jest pierwszą szkołą dla dzieci, jest niepod- 
ważalnym punktem odniesienia dla ludzi młodych i najlepszym schronieniem dla osób starszych. Dodam, że rodzina jest pierwszą szkołą miłosierdzia, ponieważ w niej jest się kochanym i uczy się kochać, doznaje się przebaczenia i uczy się przebaczać ${ }^{7}$.

\section{Przebaczenie jako wyraz osobowej dojrzalości - perspektywa biblijna}

Różne mogą być postawy wobec krzywd: można bronić się, kontratakować albo mścić się; można też cierpliwie znosić krzywdy, a nawet przebaczyć sprawcy. Jak powinno się zareagować na krzywdę? Jakie normy wyznacza w tym względzie sprawiedliwość?

Stary Testament proponuje tak zwane „prawo odwetu”: „oko za oko, ząb za ząb, rękę za rękę, nogę za nogę, oparzenie za oparzenie, ranę za ranę, siniec za siniec" (Wj 21, 24-25). Jest to bardzo prymitywne sformułowanie prawa karnego, które powinno służyć ochronie niewinnych i karaniu winnych, ograniczając jednak karę. W prymitywnym społeczeństwie, takim jakim był starożytny Izrael, prawo odwetu służyło utrzymaniu porządku i zmuszeniu do przestrzegania sprawiedliwości, unikając jednak nadmiernego karania; co więcej, w różnych przypadkach stosowano lżejsze kary (por. Wj 21, 19. 22. 26. 30). Jednakże nie brakuje tekstów, które proponującą ludziom inny sposób reakcji na zło:

Nie będziesz żywił w sercu nienawiści do brata. Będziesz upominał bliźniego, aby nie zaciagnąć winy z jego powodu. Nie będziesz szukał pomsty, nie będziesz żywił urazy do synów twego ludu, ale będziesz miłował bliźniego jak siebie samego. Ja jestem Pan! (Kpł 19, 17-18).

Nie mów: „Za zło się odpłacę”. Zdaj się na Pana: On cię wybawi (Prz 20, 22).

Nienawiść wznieca kłótnię, miłość wszelki błąd ukrywa (Prz 10, 12).

Gdy wróg twój łaknie, nakarm go chlebem, gdy pragnie, napój go wodą; żar ognia zgromadzisz na nim, a Pan ci za to zapłaci (Prz 25, 21-22).

7 Francesco, Il nome di Dio è Misericordia (Milano: PIEMME, 2016), 98; wyd. polskie: Miłosierdzie to imię Boga (Kraków: Wydawnictwo Znak, 2016). 
Radykalnej zmiany dokonuje Jezus, który formułuje diametralnie różne kryterium sprawiedliwości:

Słyszeliście, że powiedziano: „Oko za oko i ząb za ząb!” A Ja wam powiadam: Nie stawiajcie oporu złemu. Lecz jeśli cię kto uderzy w prawy policzek, nadstaw mu i drugi! Temu, kto chce prawować się z tobą i wziąć twoją szatę, odstąp i płaszcz! Zmusza cię kto, żeby iść z nim tysiąc kroków, idź dwa tysiące! Daj temu, kto cię prosi, i nie odwracaj się od tego, kto chce pożyczyć od ciebie.

Słyszeliście, że powiedziano: Będziesz miłował swego bliźniego, a nieprzyjaciela swego będziesz nienawidził. A Ja wam powiadam: Miłujcie waszych nieprzyjaciół i módlcie się za tych, którzy was prześladują; tak będziecie synami Ojca waszego, który jest w niebie; ponieważ On sprawia, że słońce Jego wschodzi nad złymi i nad dobrymi, i On zsyła deszcz na sprawiedliwych i niesprawiedliwych. Jeśli bowiem miłujecie tych, którzy was miłują, cóż za nagrodę mieć będziecie? Czyż i celnicy tego nie czynią? I jeśli pozdrawiacie tylko swych braci, cóż szczególnego czynicie? Czyż i poganie tego nie czynią? Bądźcie więc wy doskonali, jak doskonały jest Ojciec wasz niebieski (Mt 5, $38-48)$.

Papież Franciszek w książce wywiadzie mówi:

Z miłosierdziem sprawiedliwość jest bardziej sprawiedliwa, sama się naprawdę realizuje. Nie oznacza to bycia pobłażliwym, w sensie otwarcia drzwi więzień dla tych, którzy są winni poważnych przestępstw. Oznacza to, że powinniśmy pomagać podnieść się tym, którzy upadli. Trudno wprowadzić to w praktyce, ponieważ czasami wolimy zamknąc kogoś w więzieniu do końca życia, a nie starać się go odzyskać, pomagając mu zintegrować się ze społeczeństwem8.

Miłosierdzie i sprawiedliwość nie przeciwstawiają się zatem sobie, ale czynienie sprawiedliwości jest bardziej sprawiedliwe wraz z miłosierdziem.

\section{Krzywda jako dar laski}

Zgłębiając dalej to zagadnienie, można stwierdzić, że krzywda i „rana” mogą być także źródłem błogosławieństwa. Faktycznie, „tylko ten, kto został upokorzony, wie, co oznacza być pokornym”. Nie należy obawiać się

8 Tamże, 92. 
krzywd i ran. Przykładem może być przypadek Hioba ze Starego Testamentu. Hiob jest mężem sprawiedliwym, którego szatan - za Bożym przyzwoleniem - poddał twardej próbie. Wiadomo, że nie mówi się tutaj o historycznym zdarzeniu, ale o przypowieści, której celem jest przezwyciężanie „teologii wynagradzania”. Hiob był mężem sprawiedliwym, zatem z perspektywy sprawiedliwości nielogiczne były kary i próby, jakim został poddany: utrata dóbr, uczuć, godności. Ta przypowieść ukazuje Bożą i ludzką bezinteresowność, wykorzystując do tego celu odwołanie się do niesprawiedliwości i znieważenia godności Hioba. Nie kocha się po to, aby czuć się dobrze lub odnosić różnego rodzaju sukcesy. Miłość porusza sama z siebie. Dlatego Hiob, mąż sprawiedliwy, pozostaje wierny Bogu (i sobie samemu) nawet w najtrudniejszych momentach.

Miniona epoka daje nam przykłady ludzi, którzy umieli wybaczyć, aż po oddanie swojego życia: Maksymilian Kolbe, który ofiarował swoje życie za współwięźnia skazanego na śmierć; Etty Hillesum, młoda Holenderka, która okazała serdeczność hitlerowskiemu żołnierzowi, prowadzącemu ją na śmierć; Igino Giordani, który podczas I wojny światowej zdecydował nie strzelać do „wroga”, bo postrzegał go jako swojego brata, oszczędzając tym samym siły dla budowania przyszłego pokoju (był pierwszym, który mówił o klauzuli sumienia w odniesieniu do służby wojskowej); Matka Teresa z Kalkuty, która podjęła się ratowania wielu opuszczonych osób i trędowatych w Kalkucie itd. Dodałbym do tej listy jeszcze jedną postać. Były biskup Latiny (Włochy), Giuseppe Petrocchi, opowiedział o niezwykłym spotkaniu $\mathrm{z}$ matką ks. Andrei Santora, włoskiego kapłana fidei donum z Priverno w Lacjum (Włochy), który 5 lutego 2006 roku został zamordowany w Trabzon, w Turcji. Na pytanie biskupa, czy przebacza mordercy swojego syna, matka Santora odpowiedziała twierdząco. Ten pytał dalej: czy byłaby gotowa adoptować tego mordercę jako własnego syna? Potwierdziła, że tak. Biskup - na koniec mszy, wobec wszystkich - ukląkł przed matką ks. Andrei i poprosił ją o błogosławieństwo. Istotnie, nie ma większej miłości niż taka.

Mówiąc o pozytywach, jakie mogą wynikać z przeżycia cierpienia, nie sposób pominąć kwestię odporności psychicznej. Psychologia, jako nauka, zwróciła uwagę na „odporność psychiczną” jako istotną wartość dla ludzkiej egzystencji, będącą konsekwencją uporania się z cierpieniem. Odporność psychiczna jest zdolnością jednostki do zmierzenia się i przezwyciężenia traumatycznego wydarzenia lub trudnego okresu. Z krzywdą można zmierzyć się i ją przezwyciężyć. To nie znaczy, że się ją ignoruje czy poddaje się jej w sposób masochistyczny, lecz że raz doznawszy krzywdy, można wykorzystać pozytywnie nagromadzoną energię. Papież Franciszek, zwracając się 
do więźniów w Ciudad Juaréz, w Meksyku, powiedział: „Ten, kto wycierpiał największy ból i o którym moglibyśmy powiedzieć, że «doświadczył piekła», może stać się prorokiem w społeczeństwie".

Jeśli z jednej strony krzywda dotyka czegoś najbardziej intymnego, to znaczy naszego „Ja”, a poprzez przebaczenie odkrywamy nasze prawdziwe „Ja”, upodabniając się do Jezusa i tworząc „Ja” przemienione, to z drugiej strony energia, zgromadzona dzięki cierpieniu z powodu doznanej krzywdy, musi być uwolniona w sposób zdrowy, poprzez dobre czyny, podejmowanie działań solidarności międzyludzkiej. Nasze społeczeństwo zna takie przykłady. W Coimbatore, jednym z rejonów Indii, w siedzibie ruchu Shanti Ashram związanego z Mahatmą Gandhim, jego członkowie zapoczątkowali projekty socjalne, mające na celu wsparcie kobiet $\mathrm{z}$ terenów wiejskich i dzieci z ubogich rodzin. Jednym z problemów, jakie musieli rozwiązać, jest dewastacja moralna rodzin, spowodowana przede wszystkim alkoholizmem. Ojcowie wydają na alkohol niewielkie sumy, jakie posiadaja, pozbawiając swoje rodziny tego, co niezbędne do życia. Ruch Shanti Ashram otworzył na terenach wiejskich szkoły, w których dzieci otrzymują pomoc, wykształcenie i wychowanie. Projekt obejmuje także uczenie zarządzania pieniędzmi. Każde dziecko otrzymuje skarbonkę i zachęca się je, aby codziennie wrzuciło do niej jedną monetę. Kiedy skarbonka jest pełna, zostaje rozbita, a pieniądze zostają wpłacone do kasy wzajemnej pomocy. Odpowiedzialni za projekt relacjonują, że wiele matek okazuje podekscytowanie na widok pieniędzy. Czasem jest to tylko pięć euro, ale dla nich to dużo, biorąc pod uwagę ich skromne możliwości finansowe.

Szczególną dla Indii postacią jest Mahatma Gandhi, prorok działania „bez przemocy”, cierpliwie przyjmujący każdą krzywdę, a nawet śmierć. $\mathrm{Na}$ ścianie domu, w którym zmarł, znajdują się słowa:

Jeśli ktoś powiedziałby mi, że chcąc uniknąć śmierci, mam uciec w Himalaje aż do końca roku, nie zrobiłbym tego. Ponieważ wiem, że śmierć jest nieuchronna, nieważne, jakie środki zapobiegawcze podejmę. Chciałbym, abyście myśleli, że jestem jedną z nielicznych osób publicznych w Indiach, która wie, jak zadbać o własne zdrowie. Bóg wie, jak ze mną postępować. On nie pozwoli mi żyć ani minuty dłużej, niż mnie potrzebuje dla swoich celów.

${ }^{9}$ Franciszek, Papież w Ciudad Juárez: więzienia sq oznaka tego, jacy jesteśmy jako spoteczeństwo, http://www.deon.pl/religia/serwis-papieski/dokumenty/przemowienia-papieskie/ art,126,papiez-w-ciudad-jurez-wiezienia-sa-oznaka-tego-jacy-jestesmy-jako-spoleczenstwo. html?utm_source=deon\&utm_medium=link_artykul. 


\section{Specyfika postawy przebaczenia}

W kontekście prawdy o tym, że przezwyciężenie krzywdy jest drogą do osobistego rozwoju, staje się ono swoistym paradygmatem działania w kontekście krzywdy. Przyjrzyjmy się zatem bliżej przebaczeniu.

W Ewangelii św. Mateusza znajduje się istotny fragment dla naszych analiz: „Wszystko, co uczyniliście jednemu z tych braci moich najmniejszych, Mnieście uczynili. (...) Wszystko, czego nie uczyniliście jednemu z tych najmniejszych, tegoście i Mnie nie uczynili” (Mt 25, 40. 45). Z kolei w Księdze Kapłańskiej czytamy: „Dalej Pan powiedział do Mojżesza: «Mów do całej społeczności Izraelitów i powiedz im: Bądźcie świętymi, bo Ja jestem święty, Pan, Bóg wasz! (...) Nie będziesz żywił w sercu nienawiści do brata. Będziesz upominał bliźniego, aby nie zaciągnąć winy z jego powodu. Nie będziesz szukał pomsty, nie będziesz żywił urazy do synów twego ludu, ale będziesz miłował bliźniego jak siebie samego. Ja jestem Pan!»” (Kpł 19, 1-2. 17-18). Z przytoczonych słów wynika, że przebaczenie jest odniesieniem do człowieka małego, słabego, jest aktem miłosierdzia, a punktem odniesienia dla przebaczenia jest sam Bóg.

W latach 90. pod wpływem książki Henriego Nouwena ${ }^{10}$ uwaga wielu osób koncentrowała się na przypowieści o synu marnotrawnym. Autor komentuje w niej obraz „Powrót syna marnotrawnego”, namalowany przez Rembrandta, który znajduje się w Ermitażu w Sankt Petersburgu (Rosja). Przypowieść o synu marnotrawnym lub o miłosiernym ojcu ukazuje paradygmat przebaczenia, postawę głęboko zakorzenioną w miłości Boga. Fundamentem każdego dzieła miłosierdzia jest sam Bóg, który objawia swoje imię: Bóg miłosierny i przebaczający. Przypowieść o synu marnotrawnym można rozumieć w świetle tego, co jest napisane w Katechizmie Kościoła katolickiego:

Po grzechu Izraela, który odwrócił się od Boga, by czcić złotego cielca, Bóg wysłuchuje wstawiennictwa Mojżesza i zgadza się iść pośród niewiernego ludu, okazując w ten sposób swoją miłość. Gdy Mojżesz prosi, by mógł zobaczyć Jego chwałę, Bóg odpowiada: „Ja ukażę ci mój majestat i ogłoszę przed tobą imię Pana (JHWH)" (Wj 33, 18-19). Pan przechodzi przed Mojżeszem i mówi: „Jahwe, Jahwe (JHWH, JHWH), Bóg miłosierny i litościwy, cierpliwy, bogaty w łaskę i wierność" (Wj 34, 5-6). Mojżesz wyznaje wówczas, że Pan jest Bogiem, który przebacza.

${ }_{10}$ Zob. Henri Nouwen, L'abbraccio benedicente. Meditazione sul ritorno del figliol prodigo (Brescia: Queriniana, 1994). 
Imię Boże „Ja Jestem” lub „On Jest” wyraża wierność Boga, który mimo niewierności ludzkiego grzechu i kary, na jaką człowiek zasługuje, zachowuje „swą łaskę w tysiączne pokolenie” (Wj 34, 7). Bóg objawia, że jest „,bogaty w miłosierdzie" (Ef 2, 4), aż do dania swojego jedynego Syna. Jezus, oddając swoje życie, by wyzwolić nas z grzechu, objawi, że On sam nosi imię Boże: „Gdy wywyższycie Syna Człowieczego, wtedy poznacie, że JA JESTEM" $(\mathrm{J} 8,28)^{11}$.

Wspomniany obraz prowokuje jednak pytanie: czy można mówić o skrzywdzonym Ojcu? Na obrazie Rembrandta ojciec obejmuje syna dwiema rękami, różnymi od siebie: jedna jest męska, a druga kobieca. Faktycznie miłość Boga przypomina bardziej miłość matki - jest wyprzedzająca. Bóg wyprzedza w miłości, w miłości, która jest miłosierdziem, to znaczy, że jest zdolna objąć ludzką nędzę, niezdolność do kochania. Jan Paweł II stwierdził w swoim nauczaniu, że Bóg jest nie tylko Ojcem - jest także Matką. Potwierdza to także papież Franciszek, dla którego miłość objawia sie przede wszystkim w czułości.

W tym kontekście warto przytoczyć myśl Chiary Lubich, która stwierdza:

Będę podchodziła do wszystkich bliźnich, których spotkam, albo dla których pracuje, jakbym była ich matka. Matka zawsze przygarnia, zawsze pomaga, zawsze ma nadzieję, wszystko zakrywa. Matka przebacza wszystko swojemu dziecku nawet gdyby był zbrodniarzem, terrorystą. Miłość matki jest bowiem bardzo podobna do miłości Chrystusa, o której mówi św. Paweł (por. 1 Kor 13, $1-13)$.

Jeżeli będziemy mieli serce matki, albo ściślej, jeśli postanowimy mieć serce Matki najdoskonalszej, Maryi, zawsze będziemy gotowi kochać innych w każdej sytuacji. Będziemy kochali wszystkich, nie tylko członków naszego Kościoła, lecz także innych Kościołów. Nie tylko chrześcijan, lecz także muzułmanów, buddystów, hinduistów itd. Również ludzi dobrej woli. Również każdego człowieka zamieszkującego tę ziemię, ponieważ macierzyństwo Maryi ogarnia wszystkich, tak jak wszystkich ogarnęło Odkupienie ${ }^{12}$.

${ }^{11}$ Katechizm Kościoła katolickiego, nr 210-211 (Poznań: Pallottinum, 2002).

12 Chiara Lubich, L'arte di amare (Roma: Città Nuova, 2005), 38. 


\section{Sztuka miłowania i ,pakt miłosierdzia” - ku rozwiązaniom praktycznym}

Jezus przyszedł na ziemię, aby przynieść ludziom życie nieba, a jest nim miłość: „Bóg jest miłością” (1 J 4,18). Miłość jest sztuką miłowania. W tym stwierdzeniu nie odnoszę się do znanej książki Ericha Fromma, ale do tej sztuki, która znajduje swoją podstawę w Ewangelii i którą można by streścić w następujących punktach, które w Ruchu Focolari są fundamentem relacji międzyosobowych:

1. Miłować wszystkich: „Miłujmy tak, jak miłuje Bóg, wszystkich, nie robiąc różnic. (...) Miłość nie dopuszcza żadnej formy dyskryminacji"13.

2. Miłować jako pierwszy. Jest to gwarancja autentyczności, czystości i darmowości miłości ${ }^{14}$.

3. Miłować jak siebie samego. Czytamy w Ewangelii: „Miłuj swego bliźniego jak siebie samego" (Mt 19, 19). I mowa jest tu o jakimkolwiek bliźnim.

4. „Jednoczyć się”. Pisze św. Paweł: „Dla słabych stałem się słaby, by pozyskać słabych. Stałem się wszystkim dla wszystkich... aby tym liczniejsi byli ci, których pozyskam" (1 Kor 9, 22. 19). Jest to metoda uczłowieczenia Boga i przebóstwienia człowieka: Bóg stał sie człowiekiem, aby człowiek stał się Bogiem. Jest to sposób na realizację testamentu Jezusa: „Aby wszyscy stanowili jedno” (J 17, 21) ${ }^{15}$, a także racja istnienia Kościoła. To dlatego papież Franciszek zaprasza, aby miłować to, co realne, i mieć wzrok skierowany ku temu, co esencjalne ${ }^{16}$.

5. Miłować Jezusa w każdym. „Zaprawdę powiadam wam: Wszystko, co uczyniliście jednemu z tych braci moich najmniejszych, Mnieście uczynili" (Mt 25, 40).

6. Miłować się nawzajem. Jest to nowe przykazanie Jezusa: „Przykazanie nowe daję wam, abyście się wzajemnie miłowali, tak jak Ja was umiłowałem; żebyście i wy tak się miłowali wzajemnie" (J 13, 34;

13 Tamże, 27.

14 Tamże, 49.

15 Zob. tamże, 70.

16 Zob. „Messaggio del Santo Papa Francesco a firma del Cardinale Piero Parolin, in occasione del XXXV Metting per l'amicizia fra i popoli, inviato a S.E. Francesco Lambiasi, vescovi di Rimini”, w: Le periferie dell'umano, red. Emanuela Belloni, Alberto Savorana (Milano: RCS, 2014), 9-10. 
por. J 15, 12). Jezus umiłował człowieka aż po opuszczenie i śmierć. Dlatego Bóg Go wskrzesił. Drogą do pojednania ze wszystkimi jest zdolność bycia gotowym do oddania życia jedni za drugich, tak jak uczynił to Jezus, który pojednał świat ze sobą. To przyzywa łaskę obecności Chrystusa w człowieku i pomiędzy ludźmi: „Gdzie są dwaj albo trzej zebrani w imię moje, tam jestem pośród nich” (Mt 18, 20). Imię Boga brzmi „Ja Jestem”. W Chrystusie my jesteśmy.

Sztuka miłowania znajduje praktyczny wyraz w ,pakcie miłosierdzia”. Bóg zawarł ze swoim ludem przymierze, które można także nazwać paktem. Kiedy nadeszła pełnia czasów, Bóg posłał swojego Syna, ustanawiając Nowe Przymierze. W świetle tego o pierwszych chrześcijanach mówi się, że „Jeden duch i jedno serce ożywiały wszystkich, którzy uwierzyli” (Dz 4, 32). Egzegeci stwierdzająjednak, że obraz ten jest przykładem idealnej wspólnoty chrześcijańskiej, którą jest wspólnota paschalna, pojednana przez samego Chrystusa poprzez Jego śmierć i zmartwychwstanie, Nowe Przymierze. By jednak osiagnnąć taki cel - być jednym sercem i jedną duszą - w historii Kościoła utrzymywano zwyczaj zawierania przed Bogiem paktów w formie stałego porozumienia między różnymi osobami.

Podobnie było u początków Ruchu Focolari: pierwsze fokolariny we wspólnym dążeniu do chrześcijańskiej doskonałości, by być ,jednego serca i jednego ducha", zawarły najpierw pakt miłości wzajemnej, a nieco później, zdając sobie sprawę z trudności i wyzwań jakie dostrzegały, zawarły pakt miłosierdzia: „Pakt miłosierdzia, tak go potem nazywałyśmy, pakt poprzez który my, fokolariny, podejmowałyśmy wysiłek, żeby patrzeć na siebie każdego dnia na nowo, nie pamiętając wad innych, tak, jakbyśmy spotkały się po raz pierwszy, pomógł nam doskonalić miłość wzajemną"" 17 .

Porozumienia dotyczące wspólnych spraw: religijnych, politycznych, gospodarczych itp. są częścią codziennego życia. Są one także początkiem grup religijnych czy społecznych, mniej lub bardziej znanych. W przypadku „paktu miłości wzajemnej i paktu miłosierdzia” chodzi o jakość relacji międzyosobowych. Takie pakty można zawierać w rodzinie nazywanej „małym Kościołem” lub „Kościołem domowym”; we wspólnotach kościelnych - czyli „,rodzinie Bożej”; między stowarzyszeniami i ruchami, w miejscach pracy, w których można tworzyć „żywe komórki” Mistycznego Ciała Chrystusa.

${ }_{17}$ Chiara Lubich, „Paradiso '49”, w: AA. VV., Il Patto del '49 nell'esperienza di Chiara Lubich (Roma: Città Nuova, 2012), 17-18, nota 30. 
Pakty, o których mowa, można także rozszerzyć na wyznawców innych religii: żydów, muzułmanów, hinduistów, buddystów itd., a także na osoby o poglądach niereligijnych. Istnieje zasada wspólna dla wszystkich wielkich religii, jest to tak zwana złota zasada, która brzmi: „Nie czyń drugiemu tego, czego nie chciałbyś, aby czyniono tobie”, lub w sposób pozytywny: „Czyń innym tak, jakbyś chciał, aby tobie czyniono", co w wersji chrześcijańskiej brzmi: „Wszystko, co byście chcieli, żeby wam ludzie czynili, i wy im czyńcie" (por. Mt 7, 12; Łk 6, 31). W islamie obecna jest idea miłosierdzia, a buddyzm domaga się współczucia. Poznanie tych wskazań może pozwolić na odnalezienie religijnego i etycznego fundamentu do pokojowego współistnienia, w którym miłość i przebaczenie byłyby ciagle obecne.

„Złota zasada” odnosi się także do osób, które nie wyznają wiary religijnej, lecz są przekonane, że każdy mężczyzna i każda kobieta poszukują prawdy w sobie i poza sobą. Pokazuje to doświadczenie Ruchu Focolari na płaszczyźnie powadzonego przezeń dialogu ${ }^{18}$. Dostrzega się, że w tym obszarze są jeszcze niezbadane możliwości, które wydobywają dobro osoby ludzkiej ukryte w jej sumieniu. Przykładem może być także historia dialogu, jaki w ostatnich latach prowadzili papież Franciszek i Eugenio Scalfari. Jest jeszcze wiele innych przykładów wspólnego poszukiwania prawdy i prawdziwej miłości. Bóg objawił się, a Objawienie, dotarłszy do ludzi, ogarnęło wszystkich we wspólnej pielgrzymce wiary. To Objawienie dokonuje się jednak ciagle, jest to proces, który prowadzi ludzkość do pełni Prawdy, to znaczy do tego dnia, gdy człowiek ostatecznie wejdzie w Łono Ojca. Zarówno wierzący, jak i niewierzący, jako „szukający prawdy”, mogą to czynić razem, wierząc $\mathrm{w}$ wartości, które są obecne w ich sercach, sumieniach i umysłach.

Miłosierdzie nie jest tylko doświadczeniem religijnym. Ma swoją wartość także społeczną i intelektualną. Na przykład w dziedzinie psychologii i filozofii w XX wieku zwracano szczególną uwagę na empatię i sympatię (Max Scheler ${ }^{19}$, Edith Stein ${ }^{20}$, Jeremy Rifkin ${ }^{21}$ ). Do tych dwóch terminów

18 Od roku 1978 koordynuje tym Centro internazionale per il dialogo con persone di convinzioni non religiose. Zob. Persone di convinzioni non religiose, http://www.focolare. org/in-dialogo/persone-di-convinzioni-non-religiose/ oraz http://www.focolare.org/in-dialogo/persone-di-convinzioni-non-religiose/notiziario/.

19 Zob. Max Scheler, Essenza e forme della simpatia (Milano: Franco Angeli, 2010); wyd. polskie: Istota i formy sympatii (Warszawa: Państwowe Wydawnictwo Naukowe, 1980).

20 Zob. Edith Stein, Il problema dell'empatia (Roma: Studium, 2012); wyd. polskie: O zagadnieniu wczucia (Kraków: Wydawnictwo Znak, 1988).

${ }^{21}$ Zob. Jeremy Rifkin, La civiltà dell'empatia (Torino: Einaudi, 2010). 
możemy jeszcze dodać antypatię. Źródło jest zawsze to samo - pathos (uczucie, pasja):

- empatia, z gr. ćv „w” pathia, w języku niemieckim brzmi Einfühlung - w psychologii empatia to wrodzona zdolność osoby ludzkiej do stawiania się w sytuacji innej osoby, albo dokładniej, zdolność do dostrzegania jej pathos, jej uczuć;

- sympatia, z łac. sympathia, z gr. sympátheia, składa się z syn i pàthos (= uczucie) - jest to instynktowna bliskość z osobami czy rzeczami, wspólnota uczuć;

- antypatia, z gr. antipàtheia, od anti (= przeciw) i pàthos (= pasja) jest ona przeciwieństwem sympatii, to awersja do osób lub rzeczy.

\section{Wnioski końcowe}

Papież Franciszek, proponując na początku swojego pontyfikatu kulturę spotkania, wyszedł od obrazu umieszczonego na fasadzie katedry w Buenos Aires. Obraz przedstawia Józefa z braćmi i ojcem Jakubem. Jak wiadomo, z powodu zazdrości, bracia wyrządzili Józefowi wielką krzywdę, sprzedając go w niewolę. Na tę krzywdę Józef odpowiedział, gromadząc całą rodzinę.

W perspektywie życia w pojednaniu podstawa jest dialog, który pozwala ludziom się poznać, wypowiedzieć, uruchomić miłość, dojść do zgody (,jedno serce i jedna dusza”). Jednak w perspektywie chrześcijańskiej zwyczajnie ludzka zgoda nie wystarczy. Trzeba za każdym razem odbudowywać relację z Bogiem, gdyż jest ona fundamentem każdej innej relacji. Można to zrobić poprzez sakrament pokuty i pojednania. Jego poszczególne elementy: rachunek sumienia, żal za grzechy, wyznanie grzechów, rozgrzeszenie i wynagrodzenie, pomagają podjać kroki, które są niezbędne dla pojednania się z Bogiem i z ludźmi.

Na zakończenie chciałbym przytoczyć myśl Chiary Lubich z lat 50.:

Powiedzieliśmy kiedyś, że w bracie chcemy widzieć tylko Jezusa, odnosić się do Jezusa w nim, miłować w bracie Jezusa, lecz nagle przypominamy sobie, że ów brat ma taką czy inną wadę, taką czy inną niedoskonałość.

Nasze patrzenie zaczyna być skomplikowane, nie mamy już światła i błądząc, zrywamy jedność.

Możliwe, że ten brat, tak samo jak my wszyscy, popełnił błędy, lecz jak widzi go Bóg? Jaki jest jego rzeczywisty stan, jaka jest prawda o nim? Jeśli 
wobec Boga jest w porządku, Bóg już niczego nie pamięta, wszystko wymazał swoją krwią. A my - dlaczego pamiętamy?

I w tym momencie kto jest w błędzie?

Ja, który osądzam, czy brat?

Ja.

Muszę więc zacząć patrzeć na wszystko oczami Boga, w prawdzie. I zgodnie $\mathrm{z}$ tym taktować brata $\mathrm{w}$ taki sposób, żeby - jeśli niestety nie pojednał się on jeszcze z Bogiem - ciepło mojej miłości, którą jest Chrystus we mnie, doprowadziło go do skruchy, podobnie jak słońce, które wchłania i zabliźnia wiele ran.

Miłość karmi się prawdą, a prawda jest czystym miłosierdziem, w które musimy być przyobleczeni od stóp do głów, żeby móc się nazywać chrześcijanami $^{22}$.

Paradygmatyczną tego figurą jest Maryja, która umiłowała ludzkość do tego stopnia, że zrodziła Syna Bożego. Matka Miłosierdzia, „wyjaśnienie Boga", Maryja jest Matką ludzkości. Oto, co w związku z tym napisała Lubich:

Matka nie przestaje kochać syna, nawet kiedy jest zły, nie przestaje go wyczekiwać, kiedy jest daleko, i nie pragnie niczego innego, jak tylko go zobaczyć, przebaczyć mu, ponownie go objać; bo miłość matki cała tchnie miłosierdziem. Miłość matki przezwycięża jakąkolwiek bolesną sytuację lub przykrą okoliczność, w jakiej może znaleźć się dziecko.

Nigdy nie zabraknie tej Miłości, nawet gdyby jej dziecko ogarnęła zawierucha moralna, ideologiczna czy jeszcze inna.

Miłość matki, ponieważ wszystko przewyższa, pragnie wszystko przesłonić, ukryć.

Jeśli matka widzi swe dziecko w niebezpieczeństwie, bez wahania podejmuje każde ryzyko, rzuca się na przykład pod koła pociągu, jeśli miałby je przejechać, czy też rzuca się w rozszalałe morze, jeśli zagraża mu utonięcie. Miłość matki bowiem z natury mocniejsza jest od śmierci. Słyszałam o matce, która rzuciła się z balkonu swego domu, próbując ratować dziecko, które wysunęło jej się z ramion. Ten daremny, podjęty w rozpaczy czyn pokazuje, jak wielka jest matczyna miłość.

${ }^{22}$ Chiara Lubich, Jedność, red. Donato Falmi, Florence Gillet (Warszawa: Fundacja Mariapoli, 2016), 77-78. 
Jeśli tak postępują matki naturalne, można sobie doskonale wyobrazić, jak jest z Maryją, Bosko-ludzką Matką dziecka, które było Bogiem, i Matką duchową nas wszystkich!

Maryja jest Matką w całym tego słowa znaczeniu, jest prototypem macierzyństwa, a więc także miłości.

A ponieważ Bóg jest Miłościa, Ona zdaje się być jakby „wyjaśnieniem” Boga, otwartą księgą wyjaśniająca, kim jest Bóg.

Niezmierna miłość, jaka jest w Bogu, kazała Mu umrzeć za nas najbardziej okrutną śmiercią.

A wszystko po to, by nas zbawić, podobnie jak celem miłości każdej matki jest dobro jej dziecka.

Maryja, ponieważ jest Boską Matką, jest najbardziej ze wszystkich stworzeń podobna do Boga i najpełniej nam Go ukazuje.

Musimy ożywić wiarę w miłość Maryi do nas, musimy wierzyć, że kocha nas w taki właśnie sposób. A także naśladować Ją, gdyż jest Ona wzorem każdego chrześcijanina i drogą prowadzącą prosto do Boga ${ }^{23}$.

Największym wzorem przebaczenia jest Jezus ukrzyżowany i opuszczony. Komentując krzyk opuszczenia Jezusa (por. Mt 27,46; Mk 15, 34. 36-37), patriarcha ekumeniczny Bartłomiej I tak powiedział:

Jezus, Słowo Wcielone, oddalił się najdalej, jak może się oddalić upadła ludzkość. „Boże mój, Boże mój, czemuś Mnie opuścił?”. Odległość nieskończona, rozdarcie ostateczne, cud miłości. Między Bogiem i Bogiem, między Ojcem i Jego Synem Wcielonym, umieszcza się nasza rozpacz, z którą Jezus aż do końca będzie solidarny. Nieobecność Boga stwarza prawdziwe piekło. (...) Odwieczna więź Ojca i Syna staje się odległością pomiędzy niebem i piekłem. „Eloì, Eloì, lema sabachtàni?” Jakby na chwilę ukrzyżowany stał się niedowiarkiem. A więc wszystko się odwraca, w Jezusie ludzka wola, jak w Getsemani, zgadza się Ojcem. „Ojcze w ręce Twoje oddaję mego ducha” (Łk 23, 46). Otchłań rozpaczy ulatnia się, jak śmieszna kropla nienawiści w nieskończonej otchłani miłości. Odległość między Ojcem i Synem nie jest już więcej miejscem piekła, lecz Ducha ${ }^{24}$.

${ }^{23}$ Chiara Lubich, Charyzmat jedności (Kraków: Fundacja Mariapoli, Wydawnictwo M, 2007), 203-204.

${ }^{24}$ Bartłomiej, „Komentarz do Via Crucis w Koloseum, 1 kwietnia 1994”, L'Osservatore Romano 3.4 (1994): 7; cyt. za Chiara Lubich, Krzyk opuszczenia (Kraków: Fundacja Mariapoli, 2002), 68 (przyp. 4) i 26 (przyp. 4). 


\section{Zaś Chiara Lubich stwierdza:}

Jezus jest Zbawicielem, Odkupicielem, i dokonuje odkupienia, kiedy wylewa na ludzkość to, co Boskie, poprzez Ranę Opuszczenia, która jest źrenicą Oka Boga na świat; Nieskończoną Pustką, poprzez którą Bóg na nas patrzy; oknem Boga otwartym na oścież na świat i oknem ludzkości, poprzez które widać Boga $^{25}$.

W świetle powyższego można założyć, że jeśli wobec każdej doznanej krzywdy pomyśli się o Nim - Chrystusie ukrzyżowanym i opuszczonym, będzie można odnaleźć siłę do przebaczenia, uzdrawiając w sobie rany zadane przez bliźniego. I to jest miłosierdzie! Miłosierdzie jest drogą do prawdziwej przemiany relacji między ludźmi, jedyną możliwą etyką w świecie poranionym i pełnym przemocy. Przemienić relacje znaczy podnieść je od wewnątrz, tak by stały się tym, co jest ich wyjątkowym wezwaniem: być obrazem dynamiki miłości trynitarnej. Trzeba ćwiczyć w niej sztukę przebaczania i otrzymywania przebaczenia, bo to czyni każdego człowieka wolnym, a w konsekwencji uzdalnia go do budowania pojednania i pokoju.

\section{Ttum. Mariola T. Kozubek, Wojciech Czekaj}

\section{Forgiving the Harm as an Act of Mercy (Summary)}

The article discusses the issues of moulding a human ability of forgiving the harms. The point of departure is the contents of one of the "spiritual works of mercy" expressed in the imperative: "to bear wrongs patiently", which in Italian goes: "forgive the wrongs". A harm is a consequence of deed directed against human dignity. This kind of deed is always harmful and the harm requires healing. This process is completed in forgiveness. The author sees the ability of forgiving as a significant regulator of interpersonal relations, starting with these most basic (family) and ending with more complex ones (different types of groups, communities, nations). In his search for the model of forgiveness, the author reaches to the Holy Scripture and the experience of the Gift of Unity by Chiara Lubich, showing forgiveness from the theological perspective. He also offers an act of loving and pact of mercy as speci-

${ }^{25}$ Hubertus Blaumeiser, „Un mediatore che è nulla”, Nuova Umanità 3-4 (1998): 385-407 . 
fic educational tools in relation to forgiveness, introducing them as applicable also among believers of other religions and non-religious people.

Key words: forgiveness; harm; mercy; Focolare Movement; spiritual works of mercy.

\section{Przebaczenie krzywdy jako uczynek milosierdzia (Streszczenie)}

W artykule podjęto refleksję na temat kształtowania w człowieku zdolności do przebaczania krzywd. Punktem wyjścia jest treść jednego z ,uczynków miłosierdzia co do duszy”, wyrażonego w imperatywie: „krzywdy cierpliwie znosić”, który w języku włoskim brzmi: „krzywdy przebaczać”. Krzywda jest konsekwencją czynu skierowanego przeciwko godności człowieka. Taki czyn zawsze rani i dlatego krzywda wymaga uleczenia. Ów proces osiagga swą pełnię w przebaczeniu. Autor postrzega umiejętność przebaczania jako istotny regulator relacji międzyosobowych, począwszy od tych najbardziej podstawowych (rodzina) aż po bardziej złożone (różnego rodzaju grupy, wspólnoty, naród). W poszukiwaniu modelu przebaczania krzywd autor sięga do Pisma Świętego oraz doświadczenia charyzmatu jedności Chiary Lubich, ukazując przebaczenie w perspektywie teologicznej. Wysuwa także propozycję sztuki milowania i paktu milosierdzia jako konkretnych narzędzi o charakterze edukacyjnym w odniesieniu do przebaczenia, ukazując je jako możliwe do aplikacji także wśród wyznawców innych religii oraz osób o poglądach niereligijnych.

Słowa klucze: przebaczenie; krzywda; miłosierdzie; Ruch Focolari; uczynki miłosierdzia co do duszy.

\section{Bibliografia}

Accattoli, Luigi. Kiedy Papież prosi o przebaczenie. Wszystkie „,mea culpa” Jana Pawła II. Kraków: Wydawnictwo Znak, 1999.

Accattoli, Luigi. Quando il Papa chiede perdono. Tutti i mea culpa di Giovanni Paolo II. Milano: Mondadori, 1999.

Bartłomiej. „Komentarz do Via Crucis Koloseum, 1 kwietnia 1994”. L'Osservatore Romano 3.4 (1994): 7. 
Blaumeiser, Hubertus. „Un mediatore che è nulla”. Nuova Umanità 3-4 (1998): 385-407.

Brambilla, Franco G. „L'onda del rinnovamento. Rimettere al centro il primato di Dio. La radice del Vaticano II". Il Regno attualità 11 (2015): 715-719.

Francesco. Il nome di Dio è Misericordia. Milano: PIEMME, 2016.

Franciszek. Bulla Misericordiae Vultus Ojca Świętego Franciszka o nadzwyczajnym jubileuszu miłosierdzia. Wrocław: Wydawnictwo TUM, 2015.

Franciszek. Miłosierdzie to imię Boga. Kraków: Wydawnictwo Znak, 2016.

Franciszek. Papież w Ciudad Juárez: więzienia sq oznaka tego, jacy jesteśmy jako społeczeństwo. http://www.deon.pl/religia/serwis-papieski/dokumenty/ przemowienia-papieskie/art,126,papiez-w-ciudad-jurez-wiezienia-sa-oznakatego-jacy-jestesmy-jako-spoleczenstwo.html?utm_source=deon\&utm_mediu$\mathrm{m}=$ link_artykul.

Jan Paweł II. Novo millennio ineunte. Poznań: Pallotinum, 2001.

Katechizm Kościoła katolickiego. Poznań: Pallotinum, 2002.

Lubich, Chiara. Charyzmat jedności. Kraków: Fundacja Mariapoli, Wydawnictwo M, 2007.

Lubich, Chiara. Jedność, red. Donato Falmi, Florence Gillet. Warszawa: Fundacja Mariapoli, 2016.

Lubich, Chiara. Krzyk opuszczenia. Kraków: Fundacja Mariapoli, 2001.

Lubich, Chiara. L'arte di amare. Roma: Città Nuova, 2005.

Lubich, Chiara. „Paradiso '49”. W: AA. VV., Il Patto del '49 nell'esperienza di Chiara Lubich. Roma: Città Nuova, 2012.

„Messaggio del Santo Papa Francesco a firma del Cardinale Piero Parolin, in occasione del XXXV Metting per l'amicizia fra i popoli, inviato a S.E. Francesco Lambiasi, vescovi di Rimini". W: Le periferie dell'umano, red. Emanuela Belloni, Alberto Savorana. Milano: RCS, 2014.

Nouwen, Henri. L'abbraccio benedicente. Meditazione sul ritorno del figliol prodigo. Brescia: Queriniana, 1994.

Papieska Rada Iustitia et Pax. Kompendium nauki społecznej Kościoła. Kielce: Jedność, 2005.

Rifkin, Jeremy. La civiltà dell'empatia. Torino: Einaudi, 2010.

Scheler, Max. Essenza e forme della simpatia. Milano: Franco Angeli, 2010.

Scheler, Max. Istota i formy sympatii. Warszawa: Państwowe Wydawnictwo Naukowe, 1980.

Stein, Edith. Il problema dell'empatia. Roma: Studium, 2012.

Stein, Edith. O zagadnieniu wczucia. Kraków: Wydawnictwo Znak, 1988. 